\title{
TINJAUAN PSIKO-TEOLOGI TERHADAP FENOMENA KEKERASAN DALAM PACARAN PADA REMAJA
}

\author{
Mariani Harmadi \& Ruat Diana \\ Sekolah Tinggi Theologia Baptis Indonesia, Sekolah Tinggi Teologi Simpson \\ Email: marianiharmadi88@gmail.com
}

\begin{abstract}
ABSTRAK: Fenomena kekerasan dalam berpacaran bukan hanya terjadi di ruang tertutup atau pribadi saja melainkan sangat mudah ditemukan di ruang publik seperti halaman sekolah, tempat rental komputer, taman, trotoar, kendaraan umum, pada penumpang kendaraan roda dua di tengah lalu lintas. Dan ketika peristiwa itu berlangsung serta disaksikan oleh masyarakat umum, pelaku dan korban tidak merasa terganggu, rikuh, malu, atau berhenti. Padahal kekerasan dalam pacaran di kalangan remaja merupakan salah satu akses kepada kekerasan dalam rumah tangga, apabila hal ini tidak ditangani secara benar sebelum berkelanjutan dengan korban yang mengalami dampak pada fisik, psikis, sosial, moral, ekonomi dan masa depan generasi penerus. Metode yang digunakan adalah penelitian deskriptif dengan mengkaji fenomena kekerasan dalam pacaran dari sudut pandang Alkitab dan psikologi, dimana secara psikologis kekerasan seksual yang terjadi pada masa remaja berdampak negatif bagi pelaku maupun korban kekerasan seksual. Adapun kekerasan pada masa berpacaran dapat disebabkan karena remaja mengalami loncatan akibat gejolak hormon dan pesatnya teknologi informasi. Secara teologis hubungan seks sebelum menikah adalah tindakan merusak kehidupan para pelakunya dan kekerasan pada masa berpacaran merupakan tindakan yang bertentangan dengan konsep imago dei.
\end{abstract}

Kata kunci: Remaja, kekerasan dalam pacaran, Imago Dei.

\begin{abstract}
The phenomenon of dating violence does not only occur in closed or private spaces but is very easy to find in public spaces such as school yards, computer rental places, parks, sidewalks, public transportation, on two-wheeled vehicle passengers in the middle of traffic. And when the event took place and was witnessed by the general public, the perpetrators and victims did not feel disturbed, uncomfortable, embarrassed, or stopped. Whereas violence in courtship among adolescents is one access to domestic violence, if this is not handled properly before it is sustained with victims who have an impact on the physical, psychological, social, moral, economic and future generations. The method used is descriptive research by examining the phenomenon of dating violence from the perspective of the Bible and psychology, where psychologically sexual violence that occurs during adolescence has a negative impact on perpetrators and victims of sexual violence. The violence during dating can be caused by adolescents experiencing jumps due to hormone fluctuations and rapid information technology. Theologically sex before marriage is an act of destroying the lives of the perpetrators and violence during dating is an action that is contrary to the concept of Imago dei.
\end{abstract}

Keywords: Teenagers, dating violence, Imago Dei.

\section{PENDAHULUAN}

Fenomena kekerasan dalam masa berpacaran pada beberapa tahun ini mengalami peningkatan. Berbagai berita televisi, media cetak dan daring memberitakan berbagai masalah kekerasan pada masa pacaran. Penelitian Putri (2012) tentang kekerasan dalam pacaran menunjukkan wujudnya berupa kekerasan emosional, kekerasan verbal, perilaku yang suka mengontrol, kekerasan fisik, dan kekerasan seksual. Agresi pada masa berpacaran dikategorikan se- bagai physical violence, psychological abuse dan sexual coercion (Zahra \& Yanuvianti, 2017). Mendorong, memukul, menampar dan melempar bendabenda dapat dikategorikan dalam physical violence. Psychological abuse berupa teriakkan, penghinaan serta pemberian nama atau panggilan-panggilan tertentu yang sifatnya merendahkan. Sedangkan sexual coercion adalah tindakan yang melibatkan pemaksaan terhadap pasangan yang tidak menginginkan aktivitas seksual dengan menggunakan kekerasan 
verbal maupun fisik (Sari \& Rokhanawati, 2018; Satriyandari \& Oktaviani, 2017).

Wishesa dan Suprapti (2014) memaparkan tingkatan kekerasan seksual yaitu tingkatan pertama kekerasan verbal dan emosional, tingkatan kedua adalah kekerasan seksual, dan tingkatan ketiga adalah kekerasan fisik. Dari ketiganya, bentuk kekerasan yang paling sering dijumpai adalah kekerasan verbal. Sexual abuse umumnya berbentuk a) Perkosaan, dengan melakukan hubungan seks tanpa ijin pasangannya; b) Sentuhan yang tidak diinginkan kerap kali terjadi di bagian dada, bokong; c) Ciuman yang tidak diinginkan atau tanpa persetujuan (Andini, 2019). Luhulima (2000, p. 11) mengelompokkan kekerasan ini dalam bentuk fisik: memukul, menampar, menendang, mendorong, serta tindakan fisik lainnya. Secara psikologis: mengancam, memanggil dengan sebutan buruk, mencaci maki, menjelek-jelekan, berteriak. Seksual: memaksa pacarnya meraba, memeluk, mencium, hubungan seksual di bawah ancaman (Luhulima, 2000). Selain itu ada dua bentuk lain yaitu eksploitasi seksual berupa pemaksaan pada pacar untuk melakukan hubungan seksual dengan melayani orang lain baik yang bernuansa komersial ataupun tidak dan diskriminasi seksual berupa pemaksaan untuk berpakaian tertentu dengan menunjukkan organ seksual, yang menimbulkan rangsangan dengan dalih agama atau budaya tertentu untuk merendahkan perempuan pasangannya (Fitriani, 2013).

Kekerasan verbal dan emosional dapat menjadi tipe kekuasaan dan kontrol yang paling merusak, dimana salah satu pasangan secara sistematis merendahkan harga diri pasangannya dengan memanggilnya dengan sebutan buruk, membuat tuduhan, mempermalukan di depan umum, menghancurkan benda-benda yang special bagi pasangannya, mengatakan gila, menggunakan tatapan mengancam dan mengintimidasi. Diakui bahwa kekerasan verbal dan emosional merupakan jalan menuju kekerasan fisik atau kekerasan seksual (Khrisma, 2011, p. 16). Kekerasan pada masa pacaran berupa serangan seksual, fisik, maupun emosional dimaksudkan un- tuk mengontrol dan menguasai pasangannya yang kadang-kadang merupakan ekspresi kemarahan, sedangkan dating sexual violence yaitu kekerasan atau pemaksaan untuk melakukan kegiatan atau kontak seksual. Selain itu, penyebab kekerasan dalam pacaran juga dipengaruhi oleh faktor adanya mitos yang berkembang di tengah masyarakat dengan anggapan bahwa kekerasan merupakan bagian dari ungkapan rasa sayang dan cinta kasih dari pasangan, sehingga pasangan korban hanya menerima saja perlakuan semena-mena yang tidak senonoh itu, sehingga menjadi pemicu dan salah satu sebab terjadinya kekerasan pada masa pacaran.

Kekerasan pada masa pacaran terjadi dalam waktu yang relatif singkat dibanding usia hidup manusia namun dampak yang ditimbulkan akan mempengaruhi perjalanan hidup korban selanjutnya karena hal ini menyangkut segi kehidupan berikut ini: a) Dampak terhadap fisik berupa luka (kecil maupun besar), memar, lebam, bahkan kehamilan yang tak dikehendaki korban; b) Dampak psikologis, yaitu: cemas, trauma, stres, depresi, bahkan gangguan mental; c) Dampak sosial, korban tidak berani pergi atau melepaskan diri dari pelaku karena adanya pengontrolan tindakan atau rutinitas korban yang ketat sehingga menurunkan semangat hidup, rendah diri, tidak berani menjalin hubungan, produktifitas maupun prestasi; d) Dampak seksualnya, frigid akibat trauma, penyakit HIV/AIDS, cacat akibat aborsi yang tidak dilakukan ahli medis; e) Dampak ekonomi, mengalami kerugian materiil dan finansial karena pemerasan atas pemenuhan kebutuhan ekonominya saja (Safitri \& Kes, 2013).

Rumusan masalah dalam penelitian ini adalah bagaimana perspektif psiko-teologi tentang fenomena kekerasan dalam pacaran pada remaja? Tujuan penulisan artikel ini adalah untuk memaparkan tentang tinjauan psiko-teologi terhadap fenomena kekerasan dalam pacaran pada remaja.

\section{METODE}

Penelitian ini menggunakan pendekatan analisis literatur yang berkaitan dengan kekerasan da- 
lam pacaran untuk menghasilkan sebuah tinjauan tentang fenomena kekerasan dalam pacaran dengan mencermati berbagai penelitian yang sudah dipublikasikan dalam jurnal dan repository dengan akses secara daring. Pencermatan terhadap aspek psikologis dan teologis berdasarkan sumber-sumber pustaka yang relevan berkaitan dengan aspek tersebut yang pemaknaannya diwarnai dengan kegelisahan atas pengalaman menyaksikan langsung peristiwa yang terjadi di lingkungan masyarakat. Hasil analisis dari proses tersebut disajikan secara deskriptif dan pola ini menurut Darmawan (Darmawan \& Asriningsari, 2018) dapat digunakan dalam kajian teologis untuk mengemukakan sebuah pandangan secara teologis.

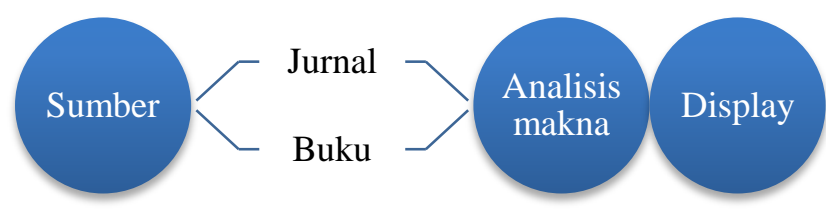

Gambar 1. Proses Penelitian

\section{PEMBAHASAN}

\section{Perspektif Teologi tentang Kekerasan Dalam Pacaran}

\section{Kasus Amnon dan Tamar}

Kasus Amnon \& Tamar merupakan salah satu wujud dari kekerasan dalam pacaran yang dicatat Alkitab (2 Sam. 13:1-22). Pemerkosaan Amnon terhadap Tamar didorong oleh hawa nafsu belaka yang membutakan akal sehatnya untuk menunda penyalurannya yang secara budaya harus dilakukan setelah proses peminangan yang berlaku pada masa itu (2 Sam 13:13). Namun rupanya nafsu birahi Amnon sudah menodai Tamar, dan tidak berhenti sampai disitu, melainkan berkembang sampai melahirkan kebencian yang amat sangat terhadap korban pelampiasannya dengan mengusir Tamar. Seperti teori Freud seorang psikoanalisis yang berpendapat bahwa faktor bakat yang terpenting pada jiwa manusia adalah naluri seksual, dimana inti dari kepribadian manusia adalah Ego yang harus menghadapi konflik antara $I d$ (yang berisi naluri-naluri seksual dan agre- sif yang selalu minta disalurkan) serta superego yang berisi larangan-larangan yang menghambat naluri-naluri itu (Sarwono, 2002; Wijaya \& Darmawan, 2019). Selanjutnya, ego masih harus mempertimbangkan realitas di dunia luar sebelum menampilkan perilaku tertentu. Sehingga Amnon -seperti teori Freud, yang dikuasai naluri seksualnya telah melampaui superegonya sehingga egonya pun tidak diberi kesempatan untuk memberi pertimbangan realitas dari luar yaitu saran Tamar untuk melalui proses peminangan yang berlaku (2 Sam 13:12-13) dengan berkata,

Tidak kakakku, jangan perkosa aku, sebab orang tidak berlaku seperti itu di Israel. Janganlah berbuat noda seperti itu. Dan aku, ke manakah kubawa kecemaranku? Dan engkau ini, engkau akan dianggap sebagai orang yang bebal di Israel. Oleh sebab itu, berbicaralah dengan raja, sebab ia tidak akan menolak memberikan aku kepadamu.

Lain halnya dengan pandangan Erikson, seorang neo-psikoanalisis yang berpendapat bahwa manusia adalah makhluk rasional yang pikiran, perasaan, dan perilakunya dikendalikan oleh ego yang lebih banyak dipengaruhi oleh faktor sosial daripada dorongan seksual. Dalam kasus Amnon pun teori Erikson masih berpadanan karena memang pada awalnya Amnon (2 Sam. 13:1-2: Amnon bin Daud jatuh cinta kepadanya. Hati Amnon sangat tergoda, sehingga ia jatuh sakit karena Tamar) secara pribadi tidak punya keberanian untuk melampiaskan dorongan seksualnya terhadap Tamar karena menurut anggapan Amnon mustahil untuk melakukan sesuatu terhadap Tamar (2 Sam. 13:2). Namun setelah Yonadab, sebagai bagian dari faktor sosial memberi solusi, maka terjadilah malapetaka itu. Dalam 2 Samuel 13:3-5:

Amnon mempunyai seorang sahabat bernama Yonadab, anak Simea kakak Daud. Yonadab itu seorang yang sangat cerdik. Katanya kepada Amnon: "Hai anak raja, mengapa engkau demikian merana setiap pagi? Tidakkah lebih baik engkau memberitahukannya kepadaku?" Kata Amnon kepadanya: "Aku cinta kepada Tamar, adik perempuan Absalom, saudaraku itu." Lalu berkatalah Yonadab kepadanya: "Berbaringlah di tempat tidurmu dan berbuat pura-pura sakit. 
Apabila ayahmu datang menengok engkau, maka haruslah engkau berkata kepadanya: Izinkanlah adikku Tamar datang memberi aku makan. Apabila ia menyediakan makanan di depan mataku, sehingga aku dapat melihatnya, maka aku akan memakannya dari tangannya.

Tampaknya dalam kasus Amnon dan Tamar, ada masalah dalam praktek Shema oleh Daud (Ul. 6:1-9) sehingga menimbulkan masalah dalam tindakan manusia. Tanggung jawab Daud dalam mendidik anaknya juga tampak bermasalah sebab Daud dalam melaksanakan peran sebagai raja kurang meluangkan waktu bagi anak-anaknya. Dalam tradisi orang Israel, Shema merupakan kaidah dalam pendidikan keluarga dengan peran utamanya adalah seorang Ayah. Darmawan (2019) mengungkapkan bahwa bangsa Israel menekankan pengajaran dengan mengulangulang sehingga terbentuk pola pemahaman yang mendasar dan terimplementasi dalam kehidupan praktis sehari-hari.

\section{Kekerasan Dalam Pacaran Dalam Perspektif Perjanjian Baru}

Pada masa Perjanjian Baru, pernikahan segera berlangsung setelah masa remaja berakhir, sehingga hubungan seks sebelum pernikahan bukan merupakan masalah yang besar seperti yang terjadi pada masa kini. Penulis Perjanjian Baru tidak banyak membahas masalah ini sesering masalah perzinahan, sebab kebanyakan pria Ibrani dewasa telah menikah pada akhir masa akil baliq (Miles, 1983, p. 203). Namun demikian Alkitab mengajarkan bahwa seks diciptakan bagi dan menjadi milik suatu pernikahan dan Alkitab mengutuk semua bentuk pelanggaran susila yang dilakukan bahkan dalam pikiran, perasaan, ucapan kata-kata, tindakan baik oleh pemuda atau dewasa baik yang sudah atau belum menikah. Kata percabulan (bahasa Yunani porneia) dalam Perjanjian Baru diartikan secara sempit sebagai hubungan seksuil yang dilakukan dengan sukarela antara seseorang yang belum menikah dengan seseorang lain yang berlainan jenis dan secara luas sebagai hubungan seks dengan seseorang yang sudah menikah serta arti yang paling luas sebagai pe- langgaran susila pada umumnya, menunjuk pada semua jenis pelanggaran seksuil (Miles, 1983, p. 204).

Bentuk lain kata percabulan (porneia, porneue, eksporneue, pornos) muncul 39 kali dalam Perjanjian Baru, antara lain: a) Percabulan menunjuk pada semua pelanggaran seksuil secara umum (Kis 15:20,29; 21:25; 1 Kor 5:1; 6:13,18; 2 Kor 12:21; Ef 5:3) dan pengertian hubungan seks seseorang yang masih lajang/bujang dengan seseorang yang telah menikah, atau antara orang-orang yang masih lajang (Miles, 1983, p. 204). Juga ada yang mengandung pengertian pelacuran, misalnya seorang wanita yang melakukan hubungan seks dengan laki-laki untuk mendapatkan sejumlah uang. Ketika kata percabulan dihubungkan dengan pelacuran, kata tersebut menunjuk kepada orang yang masih bujang, lajang atau belum menikah; b) Dalam Matius 5:32; 19:9 kata perzinahan digunakan sebagai sinomin kata percabulan; c) Dalam Matius 15:19, Markus 7:21, 22, 1 Korintus 6:9 kata perzinahan menyangkut tingkahlaku orang-orang yang telah menikah dan percabulan sebagai salah satu arti menunjuk kepada hubungan seks sebelum menikah; d) Dalam 1 Korintus 7:2 dan 1 Tesalonika 4:3-5 Paulus memperingatkan mereka yang belum menikah tentang pencobaan (percabulan) sehingga dianjurkan dengan pernikahan sebagai penangkal hidup bujang atau lajang yang tidak bermoral (yaitu hubungan seks sebelum menikah).

Berdasarkan nilai-nilai kekristenan hubungan seks sebelum menikah merusak orang lain karena dimana ada penyerang di situ ada korban dan terhadap kondisi ini, keluarga dengan asas Shema dalam pembentukan karakter dan lembaga pendidikan keagamaan yang bertanggung jawab atas pertumbuhan iman tidak dapat berdiam diri terhadap kenyataan ini. Karena Alkitab mengingatkan panggilan orang Kristen sebagai penjaga dan pelindung saudara seperti yang dikisahkan dalam Kejadian 4:9 Firman Tuhan kepada kain: "Di mana Habel, adikmu itu?" Jawabnya: "Aku tidak tahu! Apakah aku penjaga adikku?" Sebab nilai tertinggi ada pada manusia 
yang diciptakan segambar dengan Allah. Manusia memiliki nilai yang tak terbatas dalam setiap hubungan sosial. Setiap manusia berharga, apa pun kebangsaannya, warna kulit, kepercayaan ataupun kebudayaannya. Dalam pandangan Allah, semua manusia mempunyai hak dan nilai yang sama sebagai Gambar Allah yang bukan untuk disalahgunakan sebagai alat demi mencapai kepuasan dan tujuan pribadi yang mementingkan diri sendiri, melainkan untuk memuliakan Allah, Sang Pencipta. Sehingga kepada anak harus ditanamkan suatu pertanyaan sebagai bahan pertimbangan ketika anak diperhadapkan kepada pilihan untuk membuat keputusan dan bagi saudaranya bertanggung jawab untuk menjadi penjaga yang saling menjaga.

\section{Kekerasan Dalam Pacaran Dalam Perspektif Teologi Sistematika}

Konsep Imago Dei dalam diri remaja sebagai ciptaan Allah seperti juga pandangan Barth (1991, p. 50) disebut sebagai makhluk utama dan mahkota segala makhluk memerlukan semangat ketekunan untuk mengajarkannya dari generasi ke generasi (Shema) tanpa lelah. Penghargaan yang sedemikian tinggi kepada manusia sebagai ciptaan Allah walau dibentuk dari debu dan tanah merupakan modal dasar pemahaman dan keyakinan diri para remaja. Khususnya ketika mereka sedang mengalami kegalauan atas krisis perubahan dalam dirinya yang tidak seimbang ditambah pula dengan tuntutan masyarakat atasnya yang berpotensi mengaburkan konsep tentang sifat hakiki manusia dan konsep diri yang paling mendasar. Gambar Allah melekat baik kepada laki-laki maupun perempuan, artinya manusia memiliki martabat dan layak mendapat penghormatan dari sesama manusia, namun keberdosaan telah merendahkan hakekat Imago Dei. Orang tua dan gereja bertanggung jawab untuk menghidupkan kembali potensi dalam persekutuan dengan Allah sesuai dengan panggilan Allah bagi setiap umatnya. Penanaman hakekat gambar Allah dalam kehidupan anak harus dilakukan sedini mungkin sehingga karakter yang terbentuk karena benih iman yang ber- tumbuh memampukan anak melewati berbagai krisis kehidupan baik hal biologis maupun moral juga hal yang berkaitan dengan etika Kristen. Sambil tetap menjaga hak memilih yang Tuhan karuniakan kepada manusia tanpa membatasi kebebasan. Namun setiap perbudakan termasuk perbudakan seks adalah sesuatu yang tidak dapat dibenarkan.

Karena walau kitab Ulangan 4:32 mengingatkan umat Israel tentang kebesaran perbuatan Allah dalam proses penciptaan manusia, namun sama halnya dengan umat manusia pada masa kini yang seringkali menganggap dirinya sebagai makhluk yang kerdil dan rendah. Sehingga sikap penghormatan terhadap Allah Pencipta dan kepada dirinya masing-masingpun tidak sepadan dengan maksud Allah yang memberi kedaulatan untuk menjadi penguasa. Seperti halnya yang terjadi pada salah seorang manusia pertama yang merendahkan dirinya setara dengan ular padahal diberi kesempatan dan otoritas untuk mengendalikan pengambilan keputusan atas hidupnya (Kej. 3:1-5). Perendahan citra diri ini berkelanjutan dengan pembunuhan terhadap Habil (Kej 4:8) oleh kakaknya sendiri yang tidak menghargai keturunan makhluk utama ciptaan Allah.

Penghormatan manusia terhadap citra dirinya semakin merosot dengan berbagai perilaku jahat yang nampak dari penghinaan terhadap pasangan hidup dan lembaga pernikahan dengan memilih perceraian ketika terjadi masalah. Para orang tua yang menyakiti, menganiaya, memperdagangkan, menyianyiakan bahkan membunuh anak yang dipercayakan Tuhan kepadanya. Para remaja dan pemuda hidup bebas melakukan hubungan seks tanpa terikat janji nikah, bahkan sampai memiliki keberanian untuk menggugurkan kandungan dengan cara yang beresiko tinggi dari hasil hubungan di luar nikah. Padahal menurut Knoers et al (1989, p. 16) pengintegrasian Sexus (nafsu seks) dan Eros (rasa kasih yang mempunyai hakekat etis) serta berbagai macam nilai hidup dalam suatu sistem nilai pribadi bersamaan dengan penemuan diri dan pembentukan suatu rencana hidup yang pribadi adalah inti perkembangan seseorang. Krisis terhadap penghayatan nilai hidup 
terhambat dalam perkembangan hidup seorang anak manusia harus menjadi tanggung jawab para pendidik baik dalam keluarga, lembaga agama, dan lembaga pendidikan- yang terabaikan. Susanti (2016) mengungkapkan bahwa perlu sebuah pendidikan sehingga dapat membangun nilai hidup dan spiritual yang baik.

Selain juga dari tatacara berpakaian yang penuh keterbukaan dan dandanan seronok bahkan ketika hadir di rumah Tuhan untuk beribadah yang berindikasi sebagai bentuk pelecehan dan perendahan citra diri sendiri yang terus marak di kalangan para remaja yang pun seturut gambar (tselem) dengan rupa (demuth) Allah (Kej. 1:26). Namun mereka khilaf akan rancangan Allah bagi hidupnya sebagai pusat dan puncak kehidupan seperti yang difirmankan dalam Mazmur 8 (Erickson, 1998, 2003, p. 69). Hal ini perlu menjadi tantangan bagi para pendidik dengan mengenali pergumulan kaum remaja tentang identitasnya karena usaha menemukan identitas merupakan bagian normal dari proses pendewasaan, yaitu berpindah dari apa yang ditentukan oleh orang tua untuk menjadi penentu bagi dirinya sendiri terhadap pandangan hidup serta nilai-nilai dan tujuan hidupnya. Akan tetapi ada saja orangtua yang tidak benar-benar menanamkan nilai-nilai kehidupan kepada anak mereka, atau menganjurkan nilai-nilai yang mereka sendiri tidak nyatakan dalam gaya hidup mereka. Sejalan dengan perkembangan teknologi informasi yang memasuki era revolusi industri 4.0 ini dimana manusia tetap sebagai makhluk yang melampaui mesin cerdas mana pun, jika meyakini akan kebenaran bahwa permulaan pengetahuan adalah takut akan Allah (Ams. 1:7), niscaya para remaja sebagai homo informaticus diharapkan tetap membudayakan dirinya sebagai pribadi yang etis ketika berinteraksi dengan teknologi informasi yang canggih sekalipun (Kristianto, 2008, p. 138). Hal ini sejalan dengan perkembangan rohani untuk menaklukkan tubuh agar dikuasai jiwa. Karena usaha untuk pendewasaan rohani dan pengudusan hidup tidak lepas dari keadaan fisik dan mental serta emosional (Erickson, 2003, p. 126).

\section{Kekerasan Dalam Pacaran Dalam Perspektif Psikologi}

\section{Psikologi Perkembangan}

Kondisi tubuh manusia yang ditinjau dari sudut pandang psikologi perkembangan memang berpotensi memicu salah satu penyebab terjadinya kekerasan dalam pacaran yang mana hal ini jika tidak diawali dengan pendidikan psiko-edukasi dari lembaga pendidik yaitu keluarga, gereja atau sekolah, sehingga kecanggungan, kecemasan, ketakutan, ketidak-pahaman akan gejolak hormon seksual yang muncul diekspresikan dengan cara yang tidak tepat dan wajar. Berikut ini kajian dari 2 perkembangan fisik dan tugas perkembangan.

Perkembangan/pertumbuhan fisik pada masa remaja merupakan bekal bagi perlengkapan fisik manusia dewasa. Hormon-hormon seksual mulai berfungsi secara aktif, sehingga individu tidak saja dapat dibedakan secara jelas antara laki-laki (man) dan perempuan (woman), tetapi juga sebagai pria dan wanita (Sit, 2012, pp. 70-71). Perkembangan ini berpengaruh pada minat heteroseksual remaja yang secara perlahan mengarah kepada orang tertentu dari jenis seks yang berlawanan, mulai dari perhatian yang lebih bersifat genital menuju perhatian yang bersifat erotis. Pada saat ini muncul banyak cinta monyet yang diawali dengan sifat ragu-ragu dan malu-malu, kemudian perlahan-lahan berubah menjadi lebih berani, terbuka untuk kencan.

Mengenai ketuntasan tugas perkembangan dari tahap anak ke remaja/pemuda, pada setiap kelompok budaya mengharap anggotanya menguasai keterampilan tertentu dan memperoleh pola perilaku yang disetujui pada berbagai usia sepanjang rentang kehidupan, Hurlock (1953, 1980, p. 9) menamakannya sebagai tugas-tugas perkembangan (developmenttal task) yang merupakan tugas yang muncul pada saat atau sekitar suatu periode tertentu dari kehidupan, yang jika berhasil akan menimbulkan rasa bahagia dan membawa ke arah keberhasilan dalam melaksanakan tugas-tugas berikutnya. Akan tetapi, 
kalau gagal, menimbulkan rasa tidak bahagia dan kesulitan dalam menghadapi tugas-tugas berikutnya.

Menurut Mappiare (1982, p. 99) tugas-tugas perkembangan pada remaja yang berhubungan dengan seksual, yaitu: 1) Menerima keadaan fisiknya dan menerima peranannya sebagai pria atau wanita;

2) Menjalin hubungan baru dengan teman-teman sebaya baik sesama jenis maupun lain jenis kelamin; 3) Mempersiapkan diri untuk pernikahan dan hidup berkeluarga. Knoers et al (1989, p. 220) mengamati krisis remaja sebagai suatu masa dengan gejala yang menunjukkan adanya pembelokan dalam perkembangan dan suatu kepekaan serta labilitas yang meningkat. Hal ini terjadi karena dipicu oleh percepatan pertumbuhan pada periode antara usia 11 dan 13 tahun untuk anak wanita dengan permulaannya pada usia 11 tahun dan puncaknya pada usia 14 tahun. Namun hal ini tidak bersamaan waktu keberlangsungannya dengan anak laki-laki yang nampaknya lebih lambat tetapi berakhir pada usia 15 tahun (Fauziyah, 2019). Selain juga terjadinya kesenjangan antara tuntutan sosial dengan kesiapan yang belum maksimal untuk berperan sebagai orang dewasa yang mengakibatkan frustasi dan konflik batin (Suritno, 2011, p. 24). Belum lagi terjadinya penyimpangan-penyimpangan pada bentuk badan khas wanita atau khas laki-laki yang menimbulkan kegusaran karena menyangkut penampilan dirinya.

\section{Aspek Psikologi Sosial Tentang Kekerasan Dalam Pacaran}

Pengaruh budaya, lingkungan dan masyarakat mengandung dua sisi seperti pada mata uang yang satu merupakan penunjang bagi pertumbuhan anak manusia, sekaligus bisa juga menjadi penghambat bahkan penyesat. Hal ini tergantung dari bagaimana pembekalan yang mendasar dari keluarga khususnya orang tua untuk menghantar anak memasuki masa remaja yang merupakan saatnya mereka lepas dari ikatan dengan orangtua dan bergabung dengan kelompok usia sebayanya. Ritzer dan Goodman (2008) menjelaskan bahwa Weber mengamati salah satu penyebab kekerasan dalam pacaran yaitu teori kekuasaan tipe traditional authority mengenai jenis wewenang yang berkembang dalam kehidupan tradisional yang mana keabsahannya berdasarkan tradisi yang dianggap suci, yaitu patriarkhalisme tentang jenis wewenang yang didasarkan pada senioritas dimana pihak yang lebih tua atau senior dianggap memiliki kedudukan yang lebih tinggi. Contoh, sebagian masyarakat Indonesia menganut sistim ini sehingga wewenang ayah, suami, anggota tertua atau anak tertua dalam rumah tangga sangat dihormati, diutamakan dibandingkan dengan yang lebih muda. Hal ini terpola dalam kehidupan anak-anak, sehingga dalam konteks berpacaran pun, rasa ingin menguasai satu terhadap yang lain muncul. Utamanya jika dalam rumah pelaku mengalami perendahan karena status sebagai yang muda atau bahkan yang tua pun sudah terbiasa berada pada posisi sebagai yang lebih berkuasa. Namun tendensi suatu kekuasaan dalam berpacaran pun tergantung adanya peluang dari hubungan antara pihak yang memiliki kemampuan untuk melancarkan pengaruhnya dengan memerintah atau peran sebagai pengambil keputusan bagi pihak lain baik secara paksaan atau tidak. Pada umumnya laki-laki ingin menguasai perempuan dan ketika maksudnya mengalami hambatan, tidak jarang muncul sikap agresi secara fisik ataupun verbal terhadap objeknya (Susantyo, 2011, p. 189). Sehingga kekerasan dalam pacaran berpotensi terjadi di tengah masyarakat yang menganut pola patriarki dengan tambahan mitos yang berkembang bahwa kekerasan, pengekangan, dan sikap posesif yang berlebihan merupakan wujud rasa sayang dan melindungi sehingga remaja perempuan yang terpengaruh dengan mitos ini, bersikap pasif dan pasrah atas perlakuan pacarnya yang tidak senonoh sekalipun.

Ditinjau dari segi perkembangan sosial di lingkungan remaja usia 17-18 tahun mulai ada keberanian untuk saling mengajak berkencan yaitu pertemuan atau pergaulan sosial di antara anak-anak remaja dari kedua jenis seks berbeda tanpa adanya komitmen atau janji untuk nikah (Nurjanah, 2007, pp. 41, 61). Melainkan hanya sebagai kesempatan untuk belajar mengenali dan menghargai arti dan makna 
pergaulan sosial dengan berlatih bagaimana cara bersikap sebagai dan terhadap pria atau wanita; berlatih tata cara dan seni bergaul menurut standar serta norma yang berlaku bagi masing-masing jenis seks sesuai ketentuan adat istiadat yang berlaku. Sehingga bermakna untuk menetralisir ketegangan-ketegangan dan menumbuhkan kepercayaan diri serta rasa aman dalam pergaulan. Walaupun tidak semua anak mendapat kesempatan untuk kencan karena berbagai situasi antara lain ekonomi, lebih berminat terhadap study, hobby, dll. yang mana hal ini juga berpotensi menimbulkan perasaan rendah diri dan kesulitan menyesuaikan diri dalam pergaulan terhadap lawan jenisnya. Namun menurut Mead, kencan atau berpacaran ini juga bisa berpotensi untuk mereka terlalu cepat bergoing steady dengan seseorang dari jenis seks yang berlawanan, tanpa adanya suatu pilihan yang lebih luas, lebih matang dan dapat dipertanggungjawabkan.

Dengan demikian, adanya hubungan antara kegagalan kesempatan belajar secara wajar melalui kencan dengan resiko kekerasan dalam pacaran, bahwa seksualitas manusia selalu menampakkan dua fenomen, yaitu fenomen biologis dan fenomen sosial. Namun dalam perkembangannya, fenomen sosial lebih mendominasi seksualitas manusia. Bahkan seksualitas yang dewasa baru akan tercapai setelah seseorang mencapai seksualitas yang bersifat sosial (Wardhani, 2012, p. 188). Jadi perkembangan melalui dua fase yaitu fase awal, dimana seksualitas manusia masih didominasi oleh fenomen biologis dan bersifat autoerotisme yang hanya berfokus pada fisik dan diri sendiri, yang mana pelampiasannya biasa dengan melakukan masturbasi, onani, menonton atau membaca literasi pornografi. Fase kedua dimana seksualitas manusia telah berkembang menjadi dewasa karena telah bersifat sosial artinya seksualitas tidak lagi hanya bagi dirinya sendiri, melainkan telah mengarah keluar; kepada pribadi orang lain dan bagi penyempurnaan diri masing-masing seksualitas yang menjadi matang ketika seksualitas itu menjadi tugas bagi dua orang dan bersifat sosial dalam hubungan antar manusia heteroseksual.
Kekerasan dalam pacaran di kalangan remaja berdasarkan teori ini bahwa mereka masih pada fase awal yang hanya berfokus pada kebutuhan biologis bagi dirinya sendiri semata dan mengabaikan hubungan antar manusia. Sehingga remaja laki-laki berani melakukan kekerasan bahkan sampai pembunuhan ketika hasrat biologisnya lebih dominan dibandingkan faktor penyeimbang lainnya seperti kemampuan berpikir, berbela rasa, etika dan moral yang semuanya memang seharusnya sudah dibekali dalam konteks keluarga, sekolah atau lembaga pendidikan keagamaan, serta masyarakat.

\section{Strategi Menghadapi Kekerasan Dalam Pacaran}

Karena kekerasan dalam pacaran berdampak terhadap berbagai aspek kehidupan korban dan berpotensi menjadi berkelanjutan, maka tindakan preventif jauh lebih efektif daripada kuratif. Untuk itu, strategi sebagai pembekalan dan pendampingan bagi perkembangan anak memasuki usia remaja harus menjadi fokus dari para orang dewasa dalam peran sebagai pendidik, utamanya orang tua, guru, pembina dalam keagamaan, dan aparat pemerintah sebagai pelindung. Walaupun seharusnya remaja perempuan itu sendiri pun memiliki pertahanan diri terhadap gangguan dan upaya-upaya pemaksaan atau tekanan dari pihak pasangannya.

Berikut ini upaya yang antara lain dapat dilakukan remaja perempuan terhadap ketidaknyamanan dan tekanan emosional akibat kekerasan dari pasangannya yang disebut coping. Menurut Rustiana dan Cahyati (2012) coping adalah suatu proses dimana individu mencoba untuk mengelola jarak yang ada antara tuntutan-tuntutan (baik itu tuntutan yang berasal dari individu maupun tuntutan yang berasal dari lingkungan) dengan sumber-sumber daya yang mereka gunakan dalam menghadapi situasi stressful. Sedangkan menurut Mariyanti dan Karnawati (2015) coping adalah upaya kognitif dan tingkah laku untuk mengelola tuntutan internal dan eksternal yang khusus dan konflik diantaranya yang dinilai individu sebagai beban dan melampaui batas kemampuan individu tersebut, dimana individu akan memberikan 
reaksi yang berbeda untuk mengatasi stres ataupun tekanan emosional pada dirinya. Jadi coping dapat dipilih sebagai strategi merespon situasi menekan dengan fokus pada usaha mengurangi atau meminimalkan dampak dari kejadian tersebut. Bentuk dan fungsinya adalah a) Problem Focused Coping (PFC) lebih mengarah kepada upaya untuk mengurangi tuntutan dari situasi yang penuh tekanan dengan menggunakan keterampilan untuk meningkatkan percaya diri, misalnya kemampuan bela diri; b) Emotion Focused Coping (EFC) untuk mengalihkan maksud dengan pendekatan behavioral seperti olahraga, rekreasi bersama kelompok, dan pendekatan kognitif seperti negosiasi, persuasif. Sehingga bentuk-bentuk penekanan sebagai wujud otoritas yang dicobakan oleh pihak lawan jenis terhadapnya dapat diantisipasi dengan ketrampilan coping yang tentunya juga merupakan tugas pembekalan dan tanggung jawab dari para orang dewasa yang kompeten dalam hal ini dengan cara menyelenggarakan seminar, workshop, talk-show, diskusi tentang topik-topik seks, love and dating yang sehat dan aman. Riniwati (2016) menjelaskan bahwa gereja memiliki peran membekali jemaat sehingga dapat menjadi orang Kristen yang mampu menghadapi berbagai perubahan dan situasi.

\section{KESIMPULAN}

Secara psikologis kekerasan seksual yang terjadi di dalam kehidupan anak remaja berdampak

\section{DAFTAR RUJUKAN}

Andini, T. M. (2019). Identifikasi Kejadian Kekerasan Pada Anak Di Kota Malang. Jurnal Perempuan Dan Anak, 2(1), 13-28.

Barth, C., \& Frommel, M. C. B. (1991). Teologi Perjanjian Lama Jilid 1. Jakarta: BPK Gunung Mulia.

Darmawan, I. P. A. (2019). Pembelajaran Memorisasi dalam Ulangan 6:6-9. EPIGRAPHE: Jurnal Teologi dan Pelayanan Kristiani, 3(1), 25-31. negatif bagi pelaku maupun korban kekerasan seksual. Kekerasan dalam berpacaran di kalangan remaja masih pada fase awal yang hanya berfokus pada dirinya sendiri dan mengabaikan hubungan dengan orang lain. Secara psikologis kekerasan dalam pacaran dapat disebabkan karena remaja mengalami loncatan akibat gejolak hormon dan pesatnya teknologi informasi. Secara teologis hubungan seks sebelum menikah adalah merusak orang lain karena ketika terjadi penyerang maka ada korban yang tidak dapat berdiam diri terhadap kenyataan ini karena sesuai dasar Alkitab yang memanggil orang percaya sebagai penjaga dan pelindung bagi saudaranya (Kej. 4:9).

Penyelesaian masalah pada kekerasan dalam pacaran harus menjadi keprihatinan segenap lapisan masyarakat dengan mengupayakan strategi untuk menangani masalah ini yang melibatkan para pihak terkait dalam pembinaan warga jemaat yang dapat menjalin kerjasama dengan jaringan institusi yaitu keluarga dan gereja, sekolah, para profesional di bidang yang terkait seperti psikologi, hukum, kesehatan dan kebijakan pemerintah baik lokal maupun nasional.

Darmawan, I. P. A., \& Asriningsari, A. (2018). Buku Ajar Penulisan Karya Ilmiah. Ungaran: Sekolah Tinggi Teologi Simpson.

Erickson, M. J. (1998). Christian Theology (2 edition). Grand Rapids, Mich: Baker Academic.

Erickson, M. J. (2003). Teologi Kristen Vol Dua. Malang: Gandum Mas.

Fauziyah, S. A. (2019). Hubungan dukungan sosial orang tua dengan Self Efficacy pada santri remaja di Pondok Pesantren X Cianjur (Diploma, UIN Sunan Gunung Djati Bandung). 
Retrieved from http://digilib.uinsgd.ac.id/ 21236/

Fitriani, F. (2013). Faktor-Faktor Penyebab Terjadinya Eksploitasi Seksual Terhadap Anak Ditinjau Dari Sudut Kriminologi Di Kota Pontianak. Jurnal Hukum Prodi Ilmu Hukum Fakultas Hukum Untan (Jurnal Mahasiswa S1 Fakultas Hukum) Universitas Tanjungpura, 1(2). Retrieved from http://jurnal.untan.ac.id/index.php/jmfh/article/view/1821

Hurlock, E. B. (1953). Developmental psychology. New York: McGraw-Hill Book.

Hurlock, E. B. (1980). Psikologi Perkembangan suatu Pendekatan Sepanjang Rentang kehidupan. Jakarata: Erlangga.

Khrisma, V. P. (2011). Hubungan Antara Pola Asuh Otoriter Dengan Emotional Abuse Dalam Hubungan Berpacaran (Other, Prodi Psikologi Unika Soegijapranata). Retrieved from http://repository.unika.ac.id/5582/

Knoers, A. M. P., F.J.Monks, \& Siti Rahayu Handinoto. (1989). Psikologi Perkembangan Pengantar dalam berbagai Bagiannya. Yogyakarta: Gadjah Mada University Press.

Kristianto, P. L. (2008). Prinsip \& Praktik Pendidikan Agama Kristen. Yogyakarta: Andi.

Luhulima, S. (2000). Pemahaman Bentuk-bentuk Tindak Kekerasan Terhadap Perempuan dan Alternatif Pemecahan. Jakarta: PT Alumni.

Mappiare, A. (1982). Psikologi Remaja. Surabaya: Usaha Nasional.

Mariyanti, S., \& Karnawati, Y. (2015). Model Strategi Coping Penyelesaian Studi sebagai Efek Stressor serta Implikasinya terhadap Waktu Penyelesaian Studi Mahasiswa Universitas Esa Unggul: Studi pada Mahasiswa Universitas Esa Unggul yang telah Menyelesaikan Skripsi. Seminar Psikologi \& Kemanusiaan, 378-383. Malang: Universitas Muhammadiyah Malang.

Miles, H. J. (1983). Sebelum Menikah Fahamilah Seks. Jakarta: BPK Gunung Mulia.
Nurjanah, N. (2007). Perilaku Seksual Pada Remaja Yang Berpacaran dan Remaja Yang Tidak Berpacaran (Undergraduate). Universitas Islam Negeri Syarif Hidayatulah, Jakarta.

Putri, R. R. (2012). Kekerasan Dalam Berpacaran (S1, Universitas Muhammadiyah Surakarta). Retrieved from http://eprints.ums.ac.id/ $18277 /$

Riniwati, R. (2016). Bentuk Dan Strategi Pembinaan Warga Jemaat Dewasa. Prosiding Seminar Nasional Pendidikan Agama Kristen STT Simpson Tahun 2016 Tema: Strategi Pembinaan Jemaat Untuk Meningkatkan Kehidupan Jemaat, 1-13. Ungaran: Sekolah Tinggi Teologi Simpson.

Ritzer, G., \& Goodman, D. J. (2008). Teori Sosiologi: Dari Teori Sosiologi Klasik Sampai Perkembangan Mutakhir Teori Sosial Postmodern. Retrieved from //library.fis.uny.ac.id/opac/index.php?p=sho w_detail\&id=1396\&keywords=

Rustiana, E. R., \& Cahyati, W. H. (2012). Stress Kerja Dengan Pemilihan Strategi Coping. KEMAS: Jurnal Kesehatan Masyarakat, 7 (2), 149-155. https://doi.org/10.15294/ kemas.v7i2.2811

Safitri, W. A., \& Kes, S. M. (2013). Dampak Kekerasan Dalam Berpacaran. Artikel Ilmiah Hasil Penelitian Mahasiswa UNEJ, 1(1), 1-6.

Sari, D. E., \& Rokhanawati, D. (2018). The correlation between age of first dating and sexual behavior of adolescents and young adults in indonesia. Journal of Health Technology Assessment in Midwifery, 1(1), 23-28. https://doi.org/10.31101/jhtam.441

Sarwono, S. W. (2002). Psikologi Sosial: Individu dan Teori-teori Psikologi Sosial. Jakarta: Balai Pustaka.

Satriyandari, Y., \& Oktaviani, M. (2017). Hubungan Penggunaan Jenis Media Massa Dengan Kejadian Dating Violence. JHeS (Journal of Health Studies), 1(1), 78-94. https://doi.org/ 10.31101/jhes.188 
Sit, M. (2012). Perkembangan Peserta Didik. Medan: Perdana Publishing.

Suritno, S. (2011). Pengaruh ibu bekerja di luar kota terhadap kenakalan remaja di desa Luwijawa Kecamatan Jatinegara kabupaten Tegal (Undergraduate, IAIN Walisongo). Retrieved from http://eprints.walisongo.ac.id/2956/

Susanti, S. E. (2016). Spiritual Education: Solusi Terhadap Dekadensi Karakter Dan Krisis Spiritualitas Di Era Global. Humanistika, 2(1), 89-132.

Susantyo, B. (2011). MEMAHAMI PERILAKU AGRESIF: Sebuah Tinjauan Konseptual. Informasi, 16(03), 189-202.

Wardhani, D. T. (2012). Perkembangan Dan Seksualitas Remaja. Informasi, 17(03), 184-191.
Wijaya, H., \& Darmawan, I. P. A. (2019). Optimalisasi Superego dalam Teori Psikoanalisis Sigmund Freud untuk Pendidikan Karakter. Proceedings Seminar Nasional: Merajut Keragaman Untuk Mencapai Kesejahteraan Psikologis Dalam Konteks Masyarakat 5.0, 2019. https://doi.org/10.31219/osf.io/zmt6y

Wishesa, A. I., \& Suprapti, V. (2014). Dinamika Emosi Remaja Perempuan Yang Sedang Mengalami Kekerasan Dalam Pacaran. JURNAL Psikologi Pendidikan dan Perkembangan, 3(3), 159-163.

Zahra, G. P., \& Yanuvianti, M. (2017). Hubungan Antara Kekerasan dalam Berpacaran (Dating Violence) dengan Self Esteem Pada Wanita Korban KDP di Kota Bandung. Prosiding Psikologi, 3(2), 303-309. 